DOI: $10.15290 /$ bsl.2017.11.05

\author{
Aleksandra Chomiuk \\ Wydział Humanistyczny \\ Uniwersytet Marii Curie-Skłodowskiej w Lublinie \\ e-mail: aleksandra@poczta.umcs.lublin.pl
}

\title{
Doświadczenie "tamtego świata” w poezji Tomasza Różyckiego
}

Granice języka sa gdzieś w zaświatach.

Tomasz Różycki ${ }^{1}$

Przywołane w zacytowanym wyżej fragmencie wiersza Tomasza Różyckiego zaświaty to $\mathrm{w}$ tej poezji jedna $\mathrm{z}$ nazw świata „po tamtej stronie" [Je vois la suite, V, s. 25], świata lustrzanego [Dziura, A, s. 38], wyśnionego [To jest mój pokój, KO, s. 9] czy też sfalsyfikowanego i podmienionego jako „marna kopia, podróbka" [Dwudziesta ósma pieśń, ŚA, s. 160]. Przeciwstawienie „świata i antyświata" nie jest więc jednorazowym konceptem wykorzystanym w tytule tomiku, lecz ważną ontologiczną zasadą poetyckiej rzeczywistości autora Animy. Do istotnych cech tej twórczości należy również skłonność do zwielokrotnień i wariantywności formuł oraz motywów. Odnajdywane w utworach powtórzenia, zapętlenia i powroty $\mathrm{z}$ różnicą dają o sobie znać $\mathrm{w}$ tytułach wierszy z poszczególnych zbiorów („ósemki” w Księdze obrotów, Mapy, Fałszywe mapy i Spalone mapy w Koloniach, Kryzys czytelnictwa polskiego i Kryzys czytelnictwa w Literach itp.), w podporządkowywaniu tomów ogólniejszej

1 T. Różycki, Ile muzyki (Liquors \& Wines), w: tegoż, Księga Obrotów, Kraków 2010, s. 8. Przywoływane w artykule utwory Tomasza Różyckiego pochodzą z następujących wydań jego poezji: Wiersze, Warszawa 2004 - zbiór zawiera następujące tomiki: Vaterland (dalej jako V), Anima (dalej jako A), Chata umaita (dalej jako Ch), Świat i Antyświat (dalej jako ŚA); Kolonie, Kraków 2006 (dalej jako K); Księga obrotów (dalej jako KO); Litery, Kraków 2016 (dalej jako L). Tytuły cytowanych wierszy wraz z nazwą tomu oraz paginacją będą oznaczane bezpośrednio $\mathrm{w}$ tekście głównym. 
zasadzie cykliczności (wzmacnianej np. incipitami, powtarzalnością motywów, struktur wersyfikacyjnych czy numeracją tekstów), a nawet $\mathrm{w}$ tematycznych powiązaniach między utworami z różnych zbiorów (choćby wiersz Zima, zima z Vaterlandu i Szczególy z Liter czy Misja, również z Vaterlandu, zapowiadająca Kolonie).

Także ślady innych światów objawiają się $\mathrm{w}$ tej poezji od samego początku w wielu odsłonach i na różne sposoby. Zostają zarysowane przez pryzmat bardziej lub mniej jawnie eksplorowanych motywów tanatycznych, opisują odmienność w kontekście odwołań podróżniczych, są przesuwane ku fantomowej symulakryczności, modelowane jako światy z literatury, z dziecięcych marzeń czy też z historyczno-kulturowej pamięci (podkreślmy, że zaproponowane kategorie nie mają tu służyć klasyfikacji owych światów, chodzi bardziej o ogólne typy różnorodności niż o ich ścisłe rozgraniczenia). By jednak ten motyw nie stracił swojej specyfiki i nie stał się - z perspektywy proponowanej $\mathrm{w}$ artykule lektury poezji Różyckiego - po prostu wszystkim, o czym autor pisze, owe światy muszą zostać wyodrębnione i w jakiś sposób oddzielone od rzeczywistości, którą podmiot utworów, najogólniej mówiąc, dzieli z czytelnikami i poza którą usiłuje wykroczyć.

W twórczości Różyckiego wiele utworów odzwierciedla to poczucie istnienia bytów za krawędzią bytu, przeczących zdroworozsądkowym mniemaniom, by wymienić choćby wiersze To drugie życie, Ziemie odzyskane, Post scriptum, Je vois la suite, Później, w innym życiu, Prześwit (Vaterland), Dziura, Robak (Anima), List oceaniczny (Chata umaita), Pieśń dwudziesta czwarta (Hades), Dwudziesta ósma pieśń (Świat i Antyświat), Niewolnicy, Wybrzeże Moskitów (Kolonie), Tam obywaja się bez nas, Teraz łódź wpływa (Księga obrotów), Fantom, Szczegóty (Litery). W artykule odniosę się do jednej z takich sfer nierzeczywistości, jaką jest świat zmarłych.

Sposoby wykorzystywania przez poetę motywów tanatycznych to zagadnienie często podejmowane $\mathrm{w}$ poświęconych mu wypowiedziach badaczy. Zwracali oni uwagę przede wszystkim na ten typ obrazowania, który można określić - używając tu sformułowania Aliny Świeściak - jako opisy „entropicznego zmieszania” 2 . Odnajdywane w wierszach z tomów Vaterland i Anima przykłady owych przekształceń materii zyskują odniesienia somatyczne, wiążą się z metaforyką rany i organicznego rozkładu ${ }^{3}$. Nie jest to,

\footnotetext{
2 A. Świeściak, Melancholia w poezji polskiej po 1989 roku, Kraków, 2010, s. 254.

3 Następująco pisała o tych obrazach Świeściak: „Brud, śluz, błoto, «frakcje brunatne i szare», robactwo, jednym słowem «ślady okupacji» (jakie pozostawiła na przykład ustępująca zima), a więc agresji, której efektem jest rana wystawiona na działanie świata - oto ulubione pejzaże Różyckiego" [tamże, s. 273].
} 
rzecz jasna, jedyny sposób przejawiania się $\mathrm{w}$ tej poezji destrukcyjnej roli śmierci. Za pomocą skojarzeń nieco innych niż powyższe ujawnia się ona $\mathrm{np}$. w wierszu Zegar z ostatniego poetyckiego tomu. Obraz fizjologii jednostkowego umierania zostaje tu upodobniony do zniszczenia budynku, który - porzucony przez mieszkańców - zapada się w implozji, jak po wybuchu bomby, „nagle, w środku rozmowy, wytwarzając próżnię / zasysającą zasób tlenu z okolicy / spod adresów przyjaciół" [L, s. 18].

W niniejszym artykule sam ów entropiczny proces interesuje mnie bardziej jako tło dla poetyckiego zapisu przestrzenno-komunikacyjnych relacji między światem żywych i zmarłych. Zanim jednak odniosę się w sposób bardziej szczegółowy do zagadnień kreacji przez Różyckiego światów za granicą śmierci, przypomnę kilka założeń interpretacyjnych wiązanych przez badaczy z jego twórczością.

Poezja autora Liter była diagnozowana i opisywana głównie w dwu kontekstach, które w tym miejscu można umownie określić jako klasycyzujący i tożsamościowy. Pierwszy z nich wiąże się z nakładanymi na wierszowe światy znakami tradycji, przede wszystkim romantycznej ${ }^{4}$, drugi odnosi się do zagadnień poetyckiej podmiotowości, a ściślej mówiąc jej kryzysowej diagnozy, w ramach której pojawiały się określenia takie jak: podmiot wydziedziczony, wątpliwa tożsamość czy desubstancjalizacja podmiotu ${ }^{5}$. Rzecz jasna, owe konteksty nie muszą być traktowane rozłącznie. Odwoływanie się do kodów tradycji może ujawniać przesunięcie podmiotu ku jaźni słabej, znajdującej się pod wpływem splotu bardziej lub mniej sprzecznych sił postrzeganych np. w aspekcie psychoanalitycznym lub socjologicznym ${ }^{6}$. Może też ono jednak również stanowić argument za silnym podmiotem np. w sen-

4 Zob. m.in. T. Cieślak, Zaskakująca żywotność romantyzmu, w: tenże, Nowa poezja polska wobec poprzedników. Lektura relacyjna, Łódź 2011; M. Rabizo-Birek, Adam Mickiewicz w poezji Tomasza Różyckiego, w: tejże, Romantyczni i nowocześni. Formy obecności romantyzmu w polskiej literaturze wspótczesnej, Rzeszów 2012; A. Bagłajewski, Obecność romantyzmu, Lublin 2015.

5 Zob. A. Świeściak, Melancholia w poezji polskiej po 1989 roku, s. 239; J. Tabaszewska, Redefiniowanie tożsamości. Kilka uwag o konstruowaniu tożsamości w poezji Marcina Świetlickiego i Tomasza Różyckiego, w: Pęknięcia - granice - przemiany. Tożsamościowe transgresje w literaturze XX $i$ XXI wieku, red. J. Wróbel, Kraków 2013, s. 114. W pracach poświęconych poecie można dostrzec radykalizację diagnozy kryzysowego podmiotu. I tak np. Alina Świeściak w artykule z roku 2007 pisała jeszcze o "centralnym «ja» komunikującym się ze światem za pomocą pojęć odnoszących się do natury i społeczeństwa oraz wyrażanych emocji" [O dwóch przypadkach reprezentacji. Wokót motywu daty (Tomasz Różycki i Andrzej Sosnowski), „Teksty Drugie” 2007, nr 5, s. 192], natomiast już w książce trzy lata późniejszej znacznie mocniej podkreślała związane z podmiotem procesy "depersonalizacji, alienacji, poczuciu wywłaszczenia z siebie" [Melancholia w poezji polskiej po 1989 roku, s. 241].

6 Zob. J. Tabaszewska, Redefiniowanie tożsamości, s. 117-118. 
sie, w jakim pisał o tradycji Harold Bloom, w którego ujęciu skutkiem aktu twórczego określonego przez niego mianem Apophrades staje się przesunięcie relacji twórczych prowadzące do poczucia, że to nie „prekursor napisał wiersz adepta, lecz przeciwnie - że to późniejszy poeta stworzył najbardziej charakterystyczne dzieła prekursora" ${ }^{7}$.

$\mathrm{Z}$ perspektywy przyjętych $\mathrm{w}$ artykule założeń tematycznych poetyckie ,ja”" z utworów Różyckiego bardziej niż w odniesieniu do jego ontologii (czyli np. w związku ze stopniem wewnętrznej integralności) interesuje mnie jednak ze względu na przypisane podmiotowi zdolności przemieszczania się między światami i możliwości odczytywania ich znakowej natury. Spośród wypowiedzi na temat twórczości autora Dwunastu stacji najbliższa temu ujęciu jest propozycja lektury zaproponowana przez Jacka Gutorowa dotycząca poetyckich przestrzeni Różyckiego ${ }^{8}$. To, co jednak krytyk zakorzenił w realnej kartografii, ja ujmuję przede wszystkim w kontekście doznań uwalniających się od geograficznych odniesien, wpisujących się w charakterystyczny dla całej tej poezji problem nie-do-objawienia owych światów.

Należy bowiem przede wszystkim podkreślić, że jeśli wiersze autora Kolonii przywołują miejsca, gdzie ta inna rzeczywistość zbiega się z naszą, to na pewno jednak nie otwierają do niej drzwi, może czasem bywają oknem, najczęściej są czymś znacznie mniej, jedynie punktem, w którym ów „antyświat" ujawnia swą obecność, zarysowuje się na horyzoncie ludzkiego doświadczenia. Lektura zaś większości poetyckich zapisów prowadzi do wniosku o negatywnym wymiarze owego doznania: o iluzoryczności dostępu do "tamtej strony” i o jej spekulatywno-symulacyjnym charakterze.

Wyzwaniem dla podmiotu staje się więc zarówno samo przekraczanie granic, jak i stan zawieszenia $\mathrm{w}$ nierzeczywistości, do której zrozumienia brak klucza. W tym kontekście może pojawić się również jakieś „pomiędzy”, o którym w jednym z wierszy czytamy: „To jest miejsce przejściowe, skrzyżowanie świata" [Pieśń dziewiąta (Tabor), ŚA, s. 139]. Przestrzenią graniczną bywa rzeka czy - szerzej ujmując - woda. W tomie Vaterland symboliczny potencjał związany z ustanawianiem nowej rzeczywistości zostaje nałożony na realia nadodrzańskie. W Prześwicie inna rzeczywistość otwiera się "za kanałem i wyspą", gdzie być może "przechyla się ziemia” [V, s. 32]. W Ziemiach odzyskanych „druga strona”, w której będzie można „spisać konstytucję z zetlałych listów, zebrać zapomniane / klucze, przywołać umarłych na sejm

7 H. Bloom, Lęk przed wptywem. Teoria poezji, przeł. A. Bielik-Robson, M. Szuster, Kraków 2002, s. 59 .

8 J. Gutorow, Geografia sensu, sens geografii (Tomasz Różycki), w: tegoż, Niepodległość głosu. Szkice o poezji polskiej po 1968 roku, Kraków 2003, s. 151. 
za spalonym stołem" [V, s. 16], rozpoczyna się za opolskim Kanałem Ulgi. Odra niepostrzeżenie zyskuje status rzeki z mitu również w tytułowym wierszu tomu.

Marzec, sezon królowania tłustych wiatrów zza Odry. W olszynie i krzaczkach pohukują germańskie bożki. Trochę śpię, a trochę czytam, ale koniec wciąż odkładam na jutro, na dzień, kiedy przyjdzie wiosna i rzuci żagiew w środek moich snów. Trochę śpię, a trochę idę przez sen wzdłuż rzeki i wypatruję tej łodzi, czy już Dotarła do zaślinionych mgłą brzegów, czy już.

I to jest zdziecinnienie, weltschmerz, grudka soli na dnie popiołu po spalonym mieście [...]

[...] Nie mówiłem ci o tym, ale często budzę się w tej pustej łodzi, na środku rzeki i wypatruję cię na brzegu, we mgle.

[Vaterland, V, s. 21]

Kontekstem pojawiającej się $\mathrm{w}$ tym utworze sytuacji sennego błądzenia są przestrzenie kojarzone ze śmiercią: rzeka jako symbol przemijania oraz jej „zaślinione mgłą brzegi” otwierające się na krainę umarłych. Łódź płynąca na drugą stronę przywodzi na myśl przeprawę zmarłych przez Styks. Samo jednak owo przejście nie dochodzi do skutku, sen jest tu tylko próbą śmierci, nie zaś nią samą. Przebudzenie zaś ujawnia stan zawieszenia ,ja” pośrodku rzecznego nurtu9 .

Bardziej bezpośrednie mitologiczne nawiązania pojawiają się $\mathrm{w}$ wierszu Teraz łódź wpływa z Księgi obrotów. W utworze brak już jakichkolwiek informacji geograficznych przy jednoczesnym silnym skonkretyzowaniu zobrazowanych realiów. Inne niż w poprzednim wierszu jest też usytuowanie podmiotu. Nie jest on zaangażowany w rytuał, a jedynie obserwuje łódź ze zmarłym na moment przed jej pochłonięciem przez otchłań:

Teraz łódź wpływa w czarne usta rzeki.

[...] Wchodzi meandrami

w ogromne miasto, mija barki z węglem,

ludzi na moście. W łodzi jest umarły,

w cztery trumny zamknięty. [...]

\footnotetext{
9 J. Gutorow użył w odniesieniu do owej „przestrzeni pośredniej” zapożyczonego od Simone Weil słowa Metaxu [Geografia sensu, sens geografii (Tomasz Różycki), s. 154-155].
} 


\begin{abstract}
[...] Łódź płynie powoli
wśród betonowych bram, śluzą, kanałem, pod prąd tak lekko, wyrwana z niewoli

fizyki, ten jeden raz pokonanej

przez śmiechy, śpiewy, korowody w cieniu,

i znika z oczu w przejściu do podziemi.
\end{abstract}

[KO, s. 84]

"Umarły, w cztery trumny zamknięty” to Dionizos, który „wraca do domu". Jak wiadomo, kulturowe obrazy tej postaci łączą symbolikę śmierci (przypomnijmy tu za Heraklitem: „Dionizos jest Hadesem” ${ }^{10}$ ) z poczuciem niezniszczalności życia w kole jego wiecznych przeobrażeń ${ }^{11}$. Podobnie dwuznaczne skojarzenia budzi zestawienie towarzyszących bóstwu rekwizytów: „hebanowe drzewo, kwiaty/ bławatka, ołów, całun, puch topoli,/ i urny z muzyką". Jednak ostatni wers utworu jasno obrazuje, że to nie ku życiu, lecz ku śmierci zmierza łódź w kamiennym mieście ${ }^{12}$.

Uwolnienie zmarłego od praw fizyki nie jest też równoznaczne z samą łatwością przekraczania granicy między życiem i śmiercią. Proces ten, określony ironicznie $\mathrm{w}$ wierszu Je vois la suite jako „przyjemna przeprowadzka tam" [V, s. 25], bywa najczęściej ukazywany przez pryzmat naturalistycznych detali. O bolesnej poczekalni śmierci czytamy np. w utworze Siódma noc piszę ten sen:

Niebo się rozjaśnia nad Paryżem, a Słowacki ciągle pluje krwią. Gdzieś na wschodzie tęcza, dusza rozmazana wstaje jak z Sekwany chłodny wiatr.

Okno jest otwarte do pokoju i fruwają kartki, tańczy kurz.

I słychać, jak w płucach ktoś dumkę gwiżdże aż pękają pęcherzyki krwi.

Lewy anioł tam siedzi, wzór śliny z chustki czyta Jak wiersz. To się tylko zdaje - mówi. Zamieszkałem w kiczu.

Ta kartka jest otwartym oknem.

Skocz, a dam ci całe królestwo. Będziesz biegł ze wzgórza, w dole Ikwa, chłopcy pławią konie.

[V, s. 28]

\footnotetext{
10 Heraklit, Zdania, przeł. A. Czerniawski, Gdańsk 2005, s. 19.

11 Zob. K. Kerényi, Dionizos. Archetyp życia niezniszczalnego, przeł. I. Kania, Kraków 1997, s. 155.

12 Por. też uwagi M. Rabizo-Birek sytuujące ten wiersz w szerokim literackim kontekście utworów Yeatsa, Hölderlina, Celana i Różewicza [Adam Mickiewicz w poezji Tomasza Różyckiego, s. 449-450].
} 
Jest to, jak podkreślał jeden z interpretatorów, „wiersz pisany [...] umierającym ciałem, które, odchodząc $\mathrm{z}$ tego świata, prowadzi z tym światem rozrachunek" ${ }^{13}$. Zapytajmy więc o wynik owego rozrachunku. W odróżnieniu od zacytowanego wyżej badacza dostrzegam w utworze znacznie większą dozę sceptycyzmu co do możliwości przezwyciężenia śmierci ${ }^{14}$, niewiele też odczytuję w nim nadziei na możliwość powrotu do świata dzieciństwa, który miałby duchowo odnowić "ja"15. Już same bowiem słowa kierowane przez anioła do umierającego poety ujawniają swój szatański, kusicielski podtekst ${ }^{16}$. Wzór śliny $\mathrm{z}$ chustki (nasuwa się tu kolejne chrystologiczne skojarzenie: z chustą św. Weroniki) jest jedynie pustym szyfrem, który - choć czytany ,jak wiersz" - wierszem nie jest („to się tylko zdaje”). Zaś okno kartki otwierające się na idyllę dzieciństwa to we współczesnej literaturze repetycja wybrzmiewająca kiczem.

Ze zobrazowaniem uwodzicielskiej pokusy związanej z „drugą stroną” mamy do czynienia również $\mathrm{w}$ wierszu Je vois la suite:

Ach, widzę ciąg dalszy, już po tamtej stronie, to cudowne zjednoczenie, biegun tożsamości.

[V, s. 25]

Samo jednak przekraczanie tej granicy bywa trudne i bolesne:

Przy pomocy noża, stryka, czegokolwiek, przechodzi się ścianę rozpaczy, nierealną.

[V, s. 25]

Je vois la suite to zresztą wiersz szczególny nie tylko w kontrastowym zestawieniu piękna ",tamtej strony" i brzydoty samej śmierci oraz cierpień z nią

\footnotetext{
13 A. Bagłajewski, Obecność romantyzmu, s. 147.

14 Tamże, s. 148.

15 Tamże, s. 146.
}

16 Można w tym fragmencie rozpoznać odwołanie kontaminujące zapis drugiego i trzeciego kuszenia Chrystusa z Ewangelii św. Mateusza: „Wtedy wziął Go diabeł do Miasta Świętego, postawił na narożniku świątyni i rzekł Mu: «Jeśli jesteś Synem Bożym, rzuć się w dół, jest przecież napisane: Aniołom swoim rozkaże o tobie, a na rękach nosić cię będą, byś przypadkiem nie uraził swej nogi o kamień». Odrzekł mu Jezus: «Ale jest napisane także: Nie będziesz wystawiał na próbę Pana, Boga swego».

Jeszcze raz wziął Go diabeł na bardzo wysoką górę, pokazał Mu wszystkie królestwa świata oraz ich przepych i rzekł do Niego: «Dam Ci to wszystko, jeśli upadniesz i oddasz mi pokłon». Na to odrzekł mu Jezus: «Idź precz, szatanie! Jest bowiem napisane: Panu, Bogu swemu, będziesz oddawał pokłon i Jemu samemu służyć będziesz». Wtedy opuścił Go diabeł, a oto aniołowie przystąpili i usługiwali $\mathrm{Mu}^{\prime \prime}$ [Mt 4, 1-11]. http://biblia.deon.pl/rozdzial.php ?id=247 [dostęp 20.09.2017; podkr. - A.Ch.]. 
związanych (pojawiają się w tym kontekście odwołania do Adama Mickiewicza, Artura Rimbauda, Osipa Mandelsztama) czy w miłosno-śmiertelnym uwikłaniu powiązanym z kazirodczą metaforyką, ale i w samej konstrukcji uwydatniającej paradoksalność relacji łączących egzystencjalny i metatekstowy wymiar utworu. Powtarzane na jego początku i na końcu słowa: „widzę ciąg dalszy" / "Je vois la suite”, ujawniające bezgraniczność „tamtego świata", wyznaczają jednocześnie klamrową, zamkniętą kompozycję tekstu.

Przejście od "tu” do "tam" może odbywać się również poza kontrolą świadomości ${ }^{17}$, a wtedy podmiot jedynie mierzy się z jego konsekwencjami, jak w utworze Inne miejsca:

[...] Trzy razy

budzę się ze snu, nie rozpoznaję śladów. Za trzecim razem już wiem, że musiałem już wcześniej umrzeć, dawno, jeszcze dawniej,

i pochowano mnie $w$ innych miejscach, zarośniętych perzem.

Od tego właśnie powinienem zacząć.

$$
\text { [V, s. 36] }
$$

W wierszu tym śmierć jest skutkiem wygnania z raju. Ogród dzieciństwa ze „zdziczałymi jabłoniami” staje się Edenem strzeżonym przez senny koszmar, przybierający kształt opisanych w Księdze Rodzaju aniołów uzbrojonych w błyszczące miecze [Rdz 3, 24]:

Trzy razy szukam obok tej szpary, przejścia w płocie [...]

Trzy razy budzę się w nocy z krzykiem. Ciemność otwiera się tylko na moment, błysk ognistego miecza i opadają powieki.

$$
\text { [V, s. 36] }
$$

W światach rządzonych logiką sennego marzenia, charakteryzujących się prowizorycznością i tymczasowością, iluzoryczne wydają się wszelkie plany na przyszłość. Jeśli więc pojawiają się sformułowania prognozujące zmiany czy też sugerujące przyszłe działania („Dopiero tam odżyjemy”, Utopia, V, s. 13; „Niedługo odejdziemy stąd” Każdego dnia wypatruję Go, V, s. 35;

17 Do „sennego" przemieszczenia między światami dochodzi w wierszu A więc wojna, w którym czytamy: „Musieliśmy coś przegapić, widocznie dużo działo się kiedy spaliśmy, za naszymi plecami poprzesuwano meble, zmieniono oficjalny język i walutę i teraz obudziliśmy się w innym kraju" [V, s. 35]. Podobny motyw niepostrzeżonej zmiany pojawia się również w utworze I noc już przeszła: „I noc już przeszła, a ja nawet nie wiem, / jak to się stało, nie zauważyłem, / czy cień, czy ciemność. Ktoś podmienił niebo. / Byłem nietrzeźwy? Albo tylko byłem, bo byt muss sein? A teraz wskaż szczegól, / którym się różnią oba światy" [KO, s. 19]. 
„Nie będziemy tu długo" Pieśn dziewiąta (Tabor), A, s. 139; "Czekam, daj znać", Pokój, L, s. 32), to jednocześnie w punkcie, w jakim podmiot znajduje się aktualnie, owe ponaglenia wydają się nieskuteczne.

Odczucia niepewności i rozproszenia, wiążące się ze stanem zawieszenia ",ja", zostają też wzmocnione poczuciem nieprzeniknioności komunikacyjnej między światami. Przypomnijmy, że problemy z odczytywaniem znaków rzeczywistości to stały motyw poezji Różyckiego. Pojawia się on już w otwierającym pierwszy tomik wierszu Koniec wieków, kontrastującym zachwyt nad bogactwem semiosfery wyrażany w początkowych wersach („Ach mówię wam, tyle znaków, tyle cudów", V, s. 5) z kończącymi utwór sygnałami poznawczej bezradności:

\section{[...] Co to wszystko może}

znaczyć, powiedzcie mi, próbowałem z nim o tym

porozmawiać, nocą jest taniej, ale zajęte,

zajęte. Rano otwieram drzwi, otwieram gazetę,

otwieram oczy, ani słowa. O mówię wam, ile znaków, ile pustych miejsc.

$$
\text { [V, s. } 5 \text { ] }
$$

Nieczytelność znaków może wynikać z ich nietrwałości, z podatności na rozkład, jak w wierszu Zima, zima:

[...] Odwijam bandaże i widzę ranę, odkrytą teraz, wystawioną na działanie światła,

które powoli przebiera zgniłe liście, podnosi zbutwiałe gałęzie, odwraca rozmyte kartki, nie rozpoznaje słów.

[V, s. 17]

\footnotetext{
O równie nieskutecznej lekturze świata czytamy też w wierszu Lato z mu$z y k a$ :
}

I co miałbym zrobić z taką wiadomością?

Oglądam przez lornetkę straconą ruinę.

Dom i ogród niszczeją, nikt nie chce go dźwigać.

Całe skrzydło zdrętwiało, mech wchodzi po stopniach,

napisy są zatarte. Język jakby obcy,

wyrazom tym brakuje poszczególnych liter,

ukradli je miejscowi. [...]. 
Reprezentatywny w tym nurcie tajemnicy jest wiersz Post scriptum ujawniający niemożność kontaktu między dwiema sferami bytu:

Wciąż czekam na list stamtąd, a dostaję inne. Z kopert wysypują się słowa, kwiaty, zeschłe liście. [...]

Wciąż żadnej wiadomości, ani nawet plotki. Choćby zza tych drzwi, może zza tej ściany. Przykładam ucho i słychać westchnienia. [...]

To niemożliwe, żeby ani słowa. tyle zostało śladów, tyle rzeczy. [...].

[V, s. 22]

Na tak zarysowanym tle słowa z ostatniej strofki utworu: „Wystarczy / zamknąć oczy, przejść przez ścianę. To musi nadejść", zdają się bardziej zaklinaniem rzeczywistości niż wyrazem rzeczywistej wiary w możliwości kontaktu.

Ciekawe dopełnienie Post scriptum, a jednocześnie odwrócenie charakteryzującej ten utwór sytuacji komunikacyjnej, stanowi wiersz Robak pisany jak gdyby spoza granicy między - tu już wyraźniej rozpoznawalnymi - światami zmarłych i żywych:

Czasem przypominam się im. Wszystkie zaginione listy przychodzą jednego dnia i palenie ich niewiele pomaga.

[...] czasem przypominam się stąd, szepcę zaklęcia cicho, bez złości. Tam zaraz krzyczą $\mathrm{w}$ nocy $[\ldots]$.

[...] Czasem wydaje mi się, że ktoś przyszedł, słychać kroki i piach sypie się do otwartych oczu. Wyobrażam sobie taki dzień.

$$
\text { [A, s. 42] }
$$

Budowaniu atmosfery niepewności i niejednoznaczności sprzyjają w tym wierszu słowa pozbawione asercji, takie jak: wydaje się, wyobrażam sobie.

Nawet jeśli w postmortalnych wierszach Różyckiego zdarzają się powroty ze świata zmarłych, to robią one jednak wrażenie przypadkowych i bezcelowych, zostają oderwane od wspólnotowych sensów, jakie ukształtowała $\mathrm{w}$ związku z tym motywem tradycja romantyczna. W utworze Wielki Tydzień pojawia się rytuał wezwania zmarłych, paradoksalnie skutecznego i nieudanego równocześnie: 


\section{[...] Wołałem w nocy i przyszli, chociaż}

nie tego chciałem, nie zapraszałem ich. Po raz kolejny rozmawialiśmy przez drzwi. Pytali, czy mogą wejść, pluli mi na drzwi. Robili znaki, krzywili się, pokazywali ręce.

[...] sypałem sól na schody, ale przeklinali, jęczeli pod oknami.

$$
\text { [A, s. 45] }
$$

Obok tego zbiorowego powstania $\mathrm{z}$ martwych, którego tłem stają się metaforyczne obrazy zainspirowane Apokalipsą św. Jana („,sabat wiatrów”, "zdarły zasłony z nieba i ukazała się nagość", biały szkielet gwiazd", "we włosy sypią popiół"), przywołane też zostaje zmartwychwstanie indywidualne, powiązane - przez tytuł wiersza - z symboliką wielkanocną. Triumfalne odrodzenie Boga-Człowieka zostaje tu jednak zastąpione nieudolną ludzką próbą naśladowania owego cudu, próbą, której skuteczności nie możemy być pewni:

[...] Rankiem próbowałem

uwierzyć i wstać, jakby nic się nie stało, jeszcze z ziemią

pod paznokciami, cały czarny od snów. [...].

[A, s. 45]

Motyw ożywania zmarłych, wyzbyty już jednak jakichkolwiek odniesień do symboliki religijnej, pojawia się również w wierszu Szczegóty:

Oto opowieść mego pomieszania: styczeń, latarnie owinięte mgłą, cukrowa wata.

Dziś rano przyszła odwilż w kraju zlodowaceń

I wypuściła zmarłych, którzy w wielkiej liczbie

obsiedli mi stół w kuchni [...].

$$
\text { [L, s. 30] }
$$

Pojawienie się zmarłych nie jest nawet w tym utworze - inaczej niż poprzednio - skutkiem wywoływania duchów. Zamiast jednoczącego obrzędu pojawia się obraz styczniowych roztopów odsłaniających zwłoki. Mimo iż martwi wkraczają do centrum domowej przestrzeni, ich wspólnota z żywymi jest tu równie iluzoryczna jak $\mathrm{w}$ wierszu Wielki Tydzień. Jeśli to bowiem literatura zwykle brała na siebie zadanie przywoływania przeszłości i utrwalania z nią więzi, to w utworze Różyckiego nie mamy do czynienia z pamięcią kojącą, uwspólniającą doświadczenia, lecz traumatyczną, symbolizowaną przez 
siedzących przy kuchennym stole zmarlych, żywiących się wydziobywanymi $\mathrm{z}$ rany robaczkami liter. Poezja staje się tu Derridiańską niezabliźnioną raną ${ }^{18}$, natomiast pismo („,robaczki liter, ich kłębiące się wciąż larwy”) stanowi efekt rozkładu i samo na ten rozkład pracuje. Co więcej, łączy się z nim zapowiedź destrukcji podmiotu („,byłem dla nich pokarmem, wylęgły się we mnie w jątrzącej ranie, w ciele, błocie, szlamie, w mule"). Byłaby to więc rana podobna do tej, która została opisana w wierszu Zima, zima; rana ciała wystawiona na działanie świat(ł)a i jak najbardziej cielesna rana świata.

Jeśli więc nawet wiersz ujawnia jakiś związek między żywymi i zmarłymi, to owe relacje nie są postrzegane przez pryzmat zobowiązań literatury, lecz raczej w kontekście praw biologii i chemii. Dopełnieniem pytania: „Czy umiesz czytać świat?”, na które zresztą odpowiedź nie pada, jest przecież stwierdzenie:

Życie, jak wiesz, to spalanie, zjadanie, rozkład substancji organicznych w rzeczy bardzo proste plus kilka nieistotnych dla chemii szczegółów.

$$
\text { [L, s. 30] }
$$

Znów mamy tu jednak jakieś szczegóły (znaki? ślady?), których odczytanie nie jest możliwe. Jeśli przyjmiemy, że dotyczą one tego, czego uchwycenie wykracza poza możliwości nauki, to należy również zwrócić uwagę, że byłby to już kolejny dyskurs, po religijnym i literackim, który ujawnił podmiotowi swoją niewystarczalność jako narzędzie oswajania entropicznej materii. „Opowieść mojego pomieszania” - jak głosi wpisana w utwór metatekstowa zapowiedź - moglibyśmy więc czytać jako zapis bezradności ,ja” w próbach zrozumienia świata, który wymyka się sensom nakładanym przez kolejne języki stosowane do jego opisu.

Czy istnieje więc $\mathrm{w}$ tej poezji jakieś współczesne non omnis moriar, umożliwiające obronę przed poczuciem rozpadającej się fizyczności? Jedna z odpowiedzi na to pytanie jawi się jako domyślny podtekst Szczegótów. Patrząc bowiem z innej strony na ową historię nieprzerwanego umierania i rozkładu, możemy dostrzec w niej również opowieść o jedynej możliwej wspólnocie żywych i umarłych realizowanej $w$ ramach powiązań na poziomie najprostszych chemicznych składników: węgla, wodoru, tlenu. "Pomieszanie” pozwala się tu również rozumieć jako wolność bycia, kim/czym się chce, skoro ów proch, w który się obrócimy, to wspólny organiczny składnik świata.

18 Zob. J. Derrida, Che cos'è la poesia?, przeł. M. P. Markowski, „Literatura na Świecie” 1998, nr 11-12, s. 159. 
Być może więc wiara w nieśmiertelność winna się odwoływać bardziej do zmienności materii niż do stałości ducha.

Taki właśnie obraz „przemijania postaci tego świata” ${ }^{19}$ jako łagodnej metamorfozy bytów podsuwa wiersz Trzecia planeta:

przychodzę tu ze względu na postać tego świata, na jej piękną właściwość, że nie chce dotrzymać

nigdy następnego dnia $w$ tej samej sukience.

Za rzeką są kominy zmieniające ciepło

we wstęgę dymu nad trawami, w sieć pajęczą, w której brodzimy. [...].

$$
\text { [L, s. 72] }
$$

Zwróćmy jednak uwagę, że ten estetyczny wymiar metamorfoz natury („piękna właściwość”) staje się coraz bardziej odległy od ludzkiego poczucia przemijania i utraty:

\section{[...] Odwraca się rzeka,}

błyska i jednym ruchem zabiera pół nieba

i kolor twych oczu. Wieczór. Tylko gwiazdy:

łuski na powiece. Dostać w jednym pakiecie świadomość plus śmiertelność, to dopiero kawał.

Mówię to w środku zimy, na trzeciej planecie od Słońca, w wirującej we wnętrzu otchłani.

$$
\text { [L, s. 72] }
$$

Zamykający wiersz obraz samotnego ,ja" w mroźnej pustce kosmosu sugerowałby niemożność włączenia w ten proces przemian również człowieka.

Wyzwalanie się spod władzy śmierci jest również tematem zaaranżowanego po chagallowsku (i dedykowanego Chagallowi) wiersza Później, w innym życiu:

Nigdy nie potrafiłem umrzeć. Nieśmiertelność jest latającą rybą z mojego snu, [...]

Nie było żadnych granic, na anielskich skrzydłach zjawiała się wciąż ta sama melodia na skrzypce, tańczyły koty z ludzką twarzą, ludzie o koźlich głowach. Byliśmy wszystkim, każdym stworzeniem;

\footnotetext{
19 Zgodnie z kolejną biblijną aluzją [1 Kor. 7, 29-31].
} 


\begin{abstract}
[...] Nieprawda,
że nie myślałem o śmierci, ale ona okazała się snem, zupełnie innym życiem. Pytałem

wszędzie i wszystkich gdzie jest kres i nigdzie się nie zatrzymywaliśmy. Czas nie zna granic, po prostu nie istnieje. To latająca ryba, a gdzieś nad nią my, nasza miłość, nasze wieczne urodziny.
\end{abstract}

[V, s. 26]

Wpisana w ten utwór wizja jest nie tyle opisem metamorfozy, co przywołaniem zjawiska swobodnego rozpłynięcia się jaźni w bezgranicznym i bezczasowym bycie. Tak postrzegana nieśmiertelność - pojawiająca się dopiero „w innym życiu”, którego warunkiem jest śmierć (,te skrzydła unosiły nas z pogromów, niebo / odwracało się nad Witebskiem i Paryżem, upadały / obłoki, a my płynęliśmy smugą sadzy z krematorium") - stanowi jednak raczej rodzaj jednorazowej, okupionej wysoką ceną "pośmiertelności”.

Pytanie o ocalającą moc poetyckiego słowa zyskuje u opolskiego poety również szersze odniesienia do problematyczności samego języka jako narzędzia wysłowienia. Sporo uwagi poświęcił Różycki temu zagadnieniu w Księdze obrotów, gdzie pojawiają się wiersze dotyczące odklejania się słów od sensów czy też niewydolności pisma (np. Układa się z językiem, Jaki tam pakt, Co to za pismo). Z tego tomu pochodzi również utwór, z którego zostało zaczerpnięte motto niniejszego artykułu. W zdaniu: "Granice języka są gdzieś w zaświatach" [Ile muzyki (Liquors E Wines), KO, s. 8] wybrzmiewa słynna formuła Ludwiga Wittgensteina dotycząca językowego charakteru ludzkiej świadomości i sposobu zakorzenienia w świecie. Tę deklarację, wpisaną w wierszu w kontekst odległy od jakichkolwiek filozoficznych uroszczeń (jest nim przecież wizyta w sklepie z alkoholem), można oczywiście potraktować jedynie jako literacki żart. Po raz kolejny mamy tu jednak do czynienia z ujawnieniem granic i ograniczeń języka.

Spróbujmy więc na koniec uogólnić problem zakresu literackiej wyrażalności świata „po tamtej stronie”. Poetycka ontologia Różyckiego jest zorientowana na podziały między jakimś „tu” i rozmaitymi „tam”. Czasem łączą się one z szerzej rozumianą pogranicznością, ustanowieniem krainy "pomiędzy", w której dryfuje się w przestrzeni snu i podświadomości. Graniczność wyznacza w tej twórczości osobliwe, a jednocześnie negatywne miejsce egzystencji. Doświadczenia związane z jedną stroną bytu nie przydają się po jego drugiej stronie. W ramach tej niedomykającej się (nie)rzeczywistości utrudnione staje się zarówno czytanie postmortalnej obcości przez pryzmat tradycji literackiej, jak i próby jej oswojenia za pomocą symboliki religijnej, 
którą poeta posługuje się $\mathrm{z}$ biegłością pozbawioną jednak wiary $\mathrm{w}$ jej moc pocieszycielską. Ostatecznie więc w odniesieniu do tego typu usytuowania na granicy światów trafne wydaje się uogólnienie zawarte $\mathrm{w}$ komentarzu Stanisława Czerniaka do książki Bernharda Waldenfelsa poświęconej fenomenologii obcości:

"Tu" i „gdzie indziej" nie zmierzają do jakiegokolwiek „nad-miejsca”, metafizycznej syntezy usytuowań przestrzennych. "Gdzie indziej” jako to, co obce, pozostaje permanentnie „na zewnątrz” tego, co własne ${ }^{20}$.

\section{Bibliografia}

Bagłajewski Arkadiusz, Obecność romantyzmu, Lublin: Wydawnictwo UMCS 2015.

Biblia Tysiąclecia. Pismo Święte Starego i Nowego Testamentu, http://biblia.deon.pl/PS/ Biblia.html [dostęp 20.09.2017].

Bloom Harold, Lęk przed wpływem. Teoria poezji, przeł. A. Bielik-Robson, M. Szuster, Kraków: Universitas 2002.

Cieślak Tomasz, Zaskakująca żywotność romantyzmu, w: tegoż, Nowa poezja polska wobec poprzedników. Lektura relacyjna, Łódź: Wydawnictwo Uniwersytetu Lódzkiego 2011, s. 29-101.

Czerniak Stanisław, Założenia i historyczne aplikacje Bernharda Waldenfelsa fenomenologii obcego, w: B. Waldenfels, Topografia obcego. Studia z fenomenologii obcego, przeł. J. Sidorek, Warszawa: Oficyna Naukowa 2002, s. VII-XXIX.

Derrida Jacques, Che cos'è la poesia?, przeł. M. P. Markowski, „Literatura na Świecie” 1998, nr 11-12, s. 155-161.

Gutorow Jacek, Geografia sensu, sens geografii (Tomasz Różycki), w: tegoż, Niepodlegtość głosu. Szkice o poezji polskiej po 1968 roku, Kraków: Znak 2003, s. 143-155.

Heraklit, Zdania, przeł. A. Czerniawski, Gdańsk: Słowo/Obraz Terytoria 2005.

Kerényi Karl, Dionizos. Archetyp życia niezniszczalnego, przeł. I. Kania, Kraków: Baran i Suszczyński 1997.

Rabizo-Birek Magdalena, Romantyczni i nowocześni. Formy obecności romantyzmu w polskiej literaturze wspótczesnej, Rzeszów: Wydawnictwo Uniwersytetu Rzeszowskiego 2012.

Różycki Tomasz, Kolonie, Kraków: Znak 2006.

Różycki Tomasz, Księga obrotów, Kraków: Znak 2010.

Różycki Tomasz, Litery, Kraków: Wydawnictwo a5 2016.

Różycki Tomasz, Wiersze, Warszawa: Lampa i Iskra Boża 2004.

20 S. Czerniak, Założenia $i$ historyczne aplikacje Bernharda Waldenfelsa fenomenologii obcego, w: B. Waldenfels, Topografia obcego. Studia z fenomenologii obcego, przeł. J. Sidorek, Warszawa 2002, s. IX. 
Świeściak Alina, Melancholia w poezji polskiej po 1989 roku, Kraków: Universitas 2010. Świeściak Alina, O dwóch przypadkach reprezentacji. Wokót motywu daty (Tomasz Różycki i Andrzej Sosnowski), „Teksty Drugie” 2007, nr 5, s. 191-201.

Tabaszewska Justyna, Redefiniowanie tożsamości. Kilka uwag o konstruowaniu tożsamości w poezji Marcina Świetlickiego i Tomasza Różyckiego, w: Pęknięcia - granice przemiany. Tożsamościowe transgresje w literaturze XX i XXI wieku, red. J. Wróbel, Kraków: Wydawnictwo Uniwersytetu Jagiellońskiego 2013, s. 105-118.

\section{The Experience of "the Other World" in Tomasz Różycki's Poetry \\ Summary}

One of the important ontological assumptions of the poetic reality created in Tomasz Różycki's poems is the multiplication of reality. The article aims to describe one of the characteristic "anti-worlds" in his work - the world of the dead. Within the analytical framework the author of the article placed the presumable lyrical ego's ability to penetrate the borders of death and his relationships with "the other side" of existence.

Keywords: poetry, existence, space, death, Tomasz Różycki 